\title{
CHANGES IN MORPHOLOGY OF RETINAL GANGLION CELLS WITH ECCENTRICITY IN RETINAL DEGENERATION
}

EE Anderson, U Greferath, EL Fletcher

Department of Anatomy and Neuroscience, University of Melbourne, Melbourne, Victoria 3010 Australia,

Running title: Ganglion cells in retinal degeneration

Word count: 3029 words Number of pages 21 pages Number of figures 6 figures

Tables: 2 tables

\section{Author for correspondence:}

Prof Erica Fletcher

Department of Anatomy and Neuroscience

University of Melbourne

Victoria, 3010

Australia

Telephone number: $+61-383443218$

Fax number: +61 -393475219

E-mail address: elf@unimelb.edu.au

Grant support: This work was supported by the NHMRC project grant (APP1021042), by Retina Australia, and the Australian Research Council, through its Special Research Initiative in Bionic Vision Science and Technology grant to Bionic Vision Australia. 


\section{Abstract}

Ganglion cells are the output neurons of the retina and are known to remodel under subtle plasticity changes following the death of photoreceptors in inherited retinal degeneration. Here, we have examined the influence of retinal eccentricity on anatomical remodelling as well as ganglion cell morphology well after photoreceptor loss. $R d 1$ mice that have a mutation in the $\beta$ subunit of phosphodiesterase 6 were used as a model of retinal degeneration and gross remodelling events were examined by processing serial sections for immunocytochemistry. Retinal wholemounts from $r d 1$ Thy1 and control Thy1 mice that contain a fluorescent protein that labels a subset of ganglion cells were processed for immunohistochemistry at 11 months of age. Ganglion cells were classified based on their soma size, dendritic field size and dendritic branching pattern and their dendritic fields were analysed for their length, area and quantity of branching points. Overall, there was more remodelling in the central compared to the peripheral retina. In addition, there was a decrease in the size and complexity of A2, B1, C1 and D type ganglion cells located in the central region of the retina. We propose that these changes in ganglion cell morphology are correlated with remodelling events in these regions and may impact the function of retinal circuitry in the degenerated retina.

Keywords: ganglion cell, Retinitis Pigmentosa, plasticity, retina, eccentricity 
Retinitis Pigmentosa is a family of inherited diseases that result in blindness. The disease targets photoreceptors with an initial degeneration of rods followed by cones (Hamel, 2006). Following complete loss of photoreceptors, neurons of the inner retina also undergo considerable plastic changes (Jones, et al., 2003, Marc, et al., 2003, Strettoi and Pignatelli, 2000, Strettoi, et al., 2003, Strettoi, et al., 2002, Greferath et al., 2015). Ganglion cells, the output cells of the retina, pass information to higher visual centres and the influence of photoreceptor degeneration on these cells is particularly important for the success of any vision restoring therapies that directly target these cells in the retina.

Our previous work, along with others, has described a number of changes in ganglion cells in the $r d 1$ retina (Damiani, et al., 2012, Grafstei, et al., 1972, O'Brien, et al., 2014, Santos, et al., 1997, Sekirnjak, et al., 2011). Notably, advanced retinal degeneration is associated with a reduction in dendritic field size and complexity (Damiani et al., 2012, Grafstei et al., 1972, O'Brien et al., 2014). Additionally, cell death has also been substantial in late stages of degeneration with one study showing that only $30 \%$ of ganglion cells remained (Santos et al., 1997). Concurrently with these documented morphology changes, several animal models have also been used to show functional changes in these ganglion cells with increased spontaneous activity (Margolis, et al., 2008, Sekirnjak et al., 2011) and higher activation thresholds required in the degenerated retina (Jensen and Rizzo, 2007, O'Hearn, et al., 2006, Suzuki, et al., 2004). All of the studies highlight that there are substantial changes in ganglion cells following photoreceptor loss. 
The progression of photoreceptor loss in the $r d l$ mouse model of retinal degeneration, which has a mutation in the $\beta$ subunit of phosphodiesterase 6 , occurs in a central to peripheral manner and at 2 months there are less than $1 \%$ of photoreceptors remaining (Jimenez, et al., 1996). The inner retina then undergoes significant remodelling events following the loss of photoreceptors (Jones et al., 2003, Marc et al., 2003, Strettoi et al., 2003). However, limited information is known about the detailed morphology of ganglion cells located at different eccentricities at later stages of degeneration.

The aim of this study was to evaluate the time course of anatomical remodelling in the central and peripheral retina and to characterize the morphology of ganglion cells in different regions of the $r d l$ mouse retina utilizing the Thyl reporter mouse to visualize full ganglion cell morphology. We quantified changes in ganglion dendritic morphology in the central and peripheral retina of Thy1-rdl mice compared to control Thy1 mice. Our results show that there were changes in the morphology of all of the ganglion cell classes examined. Evidence of gross remodelling events were also highlighted in the degenerated retina at the same time point. 


\section{Materials and Methods}

These animal procedures were undertaken with the guidelines outlined by the National Health and Medical Research Council and the ARVO Statement for the Use of Animals in Ophthalmic and Vision Research and in accordance with the University of Melbourne Animal Experimentation Ethics Committee.

\section{Animal and tissue preparation}

The mice used in this study were $r d l$ and $r d l$-Thyl mice and aged to 3, 6, 8 or 11 months. The $r d l$-Thy1 mice were a subset of those previously reported in O'Brien et al (2014). Control mice were Thy1 mice.

Mice were sacrificed by an overdose of sodium pentobarbital (Nembutal; Merial Australia, Parramatta, NSW, Australia: $60 \mathrm{mg} / \mathrm{kg}$ ). Eyes were then immediately dissected, the anterior contents discarded and the posterior eyecup fixed in one of two ways depending on the type of tissue processing to be performed. Posterior eyecups that were to be processed for resin embedding and postembedding immunocytochemistry, were fixed overnight in a solution containing $1 \%$ paraformaldehyde, $2.5 \%$ glutaraldehyde, $3 \%$ sucrose and $0.01 \%$ calcium chloride in $0.1 \mathrm{M}$ phosphate buffer $(\mathrm{PB})$ and then washed in $0.1 \mathrm{M}$ PB and stored in $0.1 \mathrm{M}$ PB at $4{ }^{\circ} \mathrm{C}$ until use. Posterior eye cups that were processed for indirect immunohistochemistry were fixed in $4 \%$ paraformaldehyde in $0.1 \mathrm{M} \mathrm{PB}$ for 30 minutes, washed in $0.1 \mathrm{M} \mathrm{PB}$, processed through graded sucrose $(10 \%, 20 \%, 30 \% \mathrm{w} / \mathrm{v}$ sucrose in $0.1 \mathrm{M} \mathrm{PB})$ and stored at $-20^{\circ} \mathrm{C}$ until use.

\section{Amino Acid Immunocytochemistry}


Posterior eyecups were dissected to provide $\sim 0.5 \mathrm{~mm} \times 0.5 \mathrm{~mm}$ tissue samples from both the central and peripheral retina. These samples were dehydrated through graded methanol solutions and embedded in Epon-Medcast resin (Ted Pella, Redding, CA). Blocks were sectioned at 350nm on an ultramicrotome using a diamond knife. Serial sections were placed in filtered $\mathrm{dH}_{2} \mathrm{O}$ and dried on a $50^{\circ} \mathrm{C}$ heater.

Amino acid immunocytochemistry was performed as previously described by Fletcher and Kalloniatis (1996) (Fletcher and Kalloniatis, 1996) and was a slight modification of Marc et al (1990) (Marc, et al., 1990). Briefly, slides were deplasticised in a solution of sodium ethoxide (containing sodium hydroxide and $100 \%$ ethanol in a 1:5 ratio). They were then processed through graded methanols of $100 \%, 60 \%$ and $30 \%$ before being washed in $0.1 \mathrm{M}$ PB. Slides were placed in $1 \%$ sodium borohydride for 30 minutes and then washed in $0.1 \mathrm{M}$ PB and dried. Slides were then incubated for 1 hour at room temperature in a blocking solution containing $5 \%$ normal goat serum, $0.8 \%$ bovine serum albamin in $0.1 \mathrm{M}$ PB. Primary antibodies (kindly donated by Robert E Marc, University of Utah) were diluted in the $1 \%$ normal goat serum in $0.1 \mathrm{~PB}$ to the appropriate concentrations and applied to retinal sections overnight: anti-glutamate 1:4500, anti- $\gamma$-amino-butyric (GABA) acid 1:4500, anti-glycine 1:4000, anti-glutamine 1:500 and anti-taurine 1:1000 (Downie, et al., 2010, Fletcher and Kalloniatis, 1996, Marc et al., 1990). These antisera are highly selective for protein glutaraldehydeconjugated amino acids, as determined by dot immunoassays with syntheticallymanufactured antigens and do not cross react with other amino acids (Marc et al., 1990, Marc, et al., 1995). The labelling pattern obtained was similar to that previously reported in rat retina (Downie et al., 2010, Downie, et al., 2007, Fletcher and Kalloniatis, 1996, Fletcher and Kalloniatis, 1997, Sun, et al., 2007). 
Following incubation in primary antibody, slides were washed in $1 \%$ normal goat serum in 0.1PB for 30minutes and then quickly rinsed in PBS and air dried. Secondary antibody was $2 \mathrm{~nm}$ gold conjugated goat anti-rabbit IgG (ProSciTech, Thuringowa, QLD, Cat\#JB15860) diluted to 1:100 in 1\% normal goat serum in 0.1M PB for 1 hour. Sections were then rinsed in PBS for 30minutes before being fixed with $1 \%$ glutaraldehyde in $0.1 \mathrm{M}$ PB for 10 minutes. Following rinsing in $0.1 \mathrm{M} \mathrm{PB}$ and $0.2 \mathrm{M}$ Citrate buffer, sections underwent silver intensification, involving the reduction of silver ions in a $1 \%(\mathrm{w} / \mathrm{v})$ silver nitrate solution to elemental silver on the surface of the secondary antibody's $2 \mathrm{~nm}$ gold particle. Slides were air dried and cover-slipped using Epon-Medcast resin (Ted Pella, Redding, CA).

\section{Immunohistochemistry}

Posterior eyecups were thawed and the retinae dissected and incubated for 3 nights at $4^{\circ} \mathrm{C}$ in rabbit anti-GFP-Alexa Fluor 488 (Invitrogen Australia, catalogue \#A11034) diluted at 1:500 in a buffer consisting of 3\% normal goat serum, $1 \%$ bovine serum albumin and $0.5 \%$ Triton $\mathrm{X}-100$ in $0.1 \mathrm{M}$ PB. Wholemount retinae were washed in $0.1 \mathrm{M}$ PB and coverslipped in mounting medium (DAKO, Carpinteria, USA).

\section{Microscopic Analysis}

All resin sections were viewed on an Axioplan microscope (Zeiss, Oberkochen, Germany) using a 20x air objective or 40x oil objective and images were captured using an attached digital camera and computer software (SPOTCam Image, version 3.5.2 for Windows, Diagnostic Instruments, Perth, WA, Australia). Wholemount retinae were viewed and imaged on a Zeiss PASCAL LSM-5 confocal microscope (Carl Zeiss, Jena, 
Germany), using objectives (x20 and $x 40$ oil) and captured at a resolution of $512 \times 512$ or $1024 \times 1024$ pixels using image browser software (Zen, Carl Zeiss) and an appropriate filter (Alexa TM 488/FITC: excitation 488nm, emission filter 522/32). Ganglion cells were identified based on the presence of an axon. Z-stack images of $1 \mu \mathrm{m}$ thickness were obtained through the entire cell and tile scans were collected for eccentricity measurements. Images were collated using Adobe Photoshop Elements 8.0 (San Jose, CA).

\section{Ganglion Cell Analysis}

\section{Dendritic stratification:}

For the classification into $\mathrm{ON}$ and OFF ganglion cells confocal Z-stack images of entire ganglion cells were projected with Imaris software (x64, v.7.7.0 Bitplane AG, Zürich, 3 Switzerland) and the obtained the 3D images turned 90 degrees so that the stratification of the dendritic tree within the IPL became obvious. Ganglion cells in both wildtype and rd1 retinae were identified as ON cells if they stratified within $0-40 \%$ of the IPL depth and as OFF cells if they stratified within 60-100\%.

\section{Dendritic field measurements:}

The ganglion cells reported here are a subset of those described in O'Brien et al (2014). Each ganglion cell was classed into a group based on methods previously described (O'Brien et al., 2014). Briefly, classification was first defined by the soma and dendritic field diameters and then further examined by the structure of the dendritic field as previously described in Sun et al, (2002). Eccentricity measurements were obtained by measuring a straight line between the soma centre and optic disk for each ganglion cell. Measurements which were $<1500 \mu \mathrm{m}$ were defined as the central retina whereas 
$>1500 \mu \mathrm{m}$ was defined as the peripheral retina. The software program ImageJ was used for all calculations (an open source Java application, version $1.44 \mathrm{p}$; National Institutes of Health, Bethesda, MD, available online at http://rsbweb.nih.gov/ij/). The structure of the dendritic field of each ganglion cell was analysed using the software program Metamorph (Molecular Devices) by automatically tracing the cell based on the intensity of GFP labelling. The total dendritic length, total dendritic area and the number of branch points was calculated for each cell and was included in this study following inspection after the automated analysis to ensure minimal dendritic overlapping with neighbouring cells.

\section{Statistical Analysis}

Two-way analyses of variances were performed for data of cell morphologies in the $r d 1$-Thy1 and control retinae at central and peripheral eccentricities using the software program SigmaStat (Aspire Software International, Ashburn, VA). The Shapiro-Wilk test was used to test the assumption of homogeneity in variances and logarithmic or squared power transformations were performed when required. Significance between the mean responses was defined when $\mathrm{p}<0.05$. Tukey's tests were performed as posthoc pairwise comparisons when the interaction terms were significant to evaluate the differences between diseases at each locations and they are presented graphically using an asterisk. The main effect of disease was tested when the interaction term was not significant and this is presented on the graphs using bold font. All values are represented as mean \pm standard error of the mean. 


\section{Results}

The major aim of this study was to evaluate whether the morphology of ganglion cells in the $r d 1$-Thy1 retina changes with respect to eccentricity. To do this we analysed the inner retina at three different time points during degeneration (3, 6 and 11 months) to determine gross remodelling events in different regions of the retina at these ages. We then analysed the effect that these events may have on ganglion cell morphology by analysing ganglion cells in the central and peripheral regions of the degenerated retina at 11 months of age, a time point when the highest number of remodelling events were noted.

\section{Cell changes in the central and peripheral retina}

We first confirmed the extent of inner retinal remodelling in the $r d l$ retina. The amino acids glutamate, GABA and glycine label virtually all neurons in the rodent retina (Downie et al., 2010, Downie et al., 2007, Fletcher and Kalloniatis, 1996, Kalloniatis and Fletcher, 1993, Marc, et al., 2008, Marc et al., 1990, Marc, et al., 1998, Sun et al., 2007). Therefore, we used post-embedding immunocytochemistry in serial sections to localize macroscopic changes in neurons. We examined $r d 1$ retina at 3-5, 6-8 and 11 months old for anatomical changes in neurons and glia within the central retina compared with the peripheral retina. The samples were $1116.3 \pm 37.1 \mu \mathrm{m}$ in length in the central retina and $870.1 \pm 74.6 \mu \mathrm{m}$ in the peripheral region. Examples of the changes that were noted include the formation of cells stacked onto each other forming cell columns (Figure $1 \mathrm{a}-\mathrm{c}$ ), processes from inner retinal neurons being mislocated into distal regions of the retina (Figure $1 \mathrm{~d}-\mathrm{f}$ ) and thickening of Müller cell processes in the subretinal position (Figure $1 \mathrm{~g}, \mathrm{~h}$ ). In all samples at each age group there was more of an abundant of anatomical changes in the central retina than the peripheral retina (Figure $1 \mathrm{i}$ ). 
In order to gain an appreciation for changes in the number of Thy1 labelled ganglion cells at the different stages of degeneration, we quantified the number of labelled cells in control Thy 1 and $r d 1$-Thy1 retinae at $3(n=4), 6(n=5)$ and 11 months $(n=6)$ of age. These values are given in Table 2. There was no difference in the number of Thy 1 positive ganglion cells in the central retina of Thy-1 and $r d 1$-Thy1 retinae at any of the ages examined (Age: $\mathrm{F}_{(1,21)}=0.879, \mathrm{p}=0.359$; Animal type: $\mathrm{F}_{(2,21)}=0.193, \mathrm{p}=0.826$ ). In contrast, there was a decrease in the number of Thy-1 labelled ganglion cells in the peripheral retina of $r d 1$-Thy1 retinae compared to Thy-1 controls $\left(\mathrm{F}_{(1,21)}=13.731\right.$, $\mathrm{p}=0.001)$.

\section{Morphological changes in ganglion cell stratification in rd1 retina}

In order to classify ganglion cells into mono-stratified ON- and OFF-type or ON/OFF bi-stratified ganglion cells the dendritic stratification pattern was analysed. Ganglion cells were identified as ON cells if they stratified within $0-40 \%$ of the IPL depth and as OFF cells if they stratified within $60-100 \%$ (Figure 2a-d). Ganglion cells of all types were observed in both wildtype and rd1 retinae. Interestingly, we observed signs of remodelling of ganglion cell dendrites in rd1 retinae. Dendrites of mainly ON ganglion cells, which were clearly classified into a mono-stratified type often were not entirely confined to a single layer but single dendritic branches were found to weer out into neighbouring layers towards the OFF layer (Figure 2c, d).

\section{Ganglion cells in the central and peripheral retina}

In order to further analyse the morphology of the dendritic tree of ganglion cells across the entire retina we analysed 80 ganglion cells in the control retina and 75 ganglion 
cells in the $r d 1$-Thy1 retina and classified them into groups A2, B1, C1 and D (Table 1). Comparisons between degenerated and control retina showed clear changes for all cell types examined. A2 type ganglion cells showed a significant decrease for the total dendritic length in the central retina and, overall, this cell class also showed significant decreases in the total dendritic area and the number of branch points in the $r d l$-Thy1 retina irrespective of eccentricity (Figure 3 c-e). B1 type ganglion cells showed a significant decrease in the total dendritic length and total dendritic area of ganglion cells identified in the $r d 1$-Thy1 retina (Figure 4 c,d). C1 (Figure 5 c-e) and D (Figure 6 c-e) type ganglion cells showed substantial changes with both cell classes showing a significant decrease in the total dendritic length, total dendritic area and the number of branch points in the central retina of $r d l$-Thy1 animals.

We also compared the eccentricity of ganglion cells in the control and $r d 1$-Thy1 retina separately. Some analysis parameters showed a difference between central and peripheral regions of the control retina. Specifically, A2 type ganglion cells showed a significantly larger dendritic field length in the central retina $(\mathrm{p}=0.011)$ and $\mathrm{C} 1$ type ganglion cells showed a significantly larger dendritic field area $(p=0.008)$ and the number of branch points $(\mathrm{p}=0.019)$ in the central retina compared with ganglion cells identified in the peripheral region. D type ganglion cells were the only cell type to show any differences between ganglion cells in the central region compared with the peripheral region in $r d 1$-Thy1 retinae. There was a significant decrease in the dendritic field area $(\mathrm{p}=0.012)$ of ganglion cells in the central retina. 


\section{Discussion}

\section{Morphology changes do depend on eccentricity}

The results in this study indicate that ganglion cells in the degenerated retina undergo morphological change in agreement with several other reports (Damiani et al., 2012, Grafstei et al., 1972, O'Brien et al., 2014). The current study has also shown that most ganglion cells susceptible to changes in their morphology were present in the central region of the $r d l$ mouse model of degeneration. This is in contrast to a previous study which did not show any differences between ganglion cells in the central and peripheral regions (Lin and Peng, 2013). The differences noted here are possibly due to the greater sample size of cells that were analysed. Additionally, this study also showed that in the normal retina there are differences in ganglion cells sizes across the retina in some classes of cells which has also been found in other animal models (Wassle and Boycott, 1991) and humans (Dacey and Petersen, 1992).

\section{Morphology changes are most likely driven by remodelling events}

There are a variety of underlying causes that might explain the morphological changes described in this study. First, cell loss could contribute to changes in morphology. Specifically, ganglion cells may spread to cover larger areas of the retina to encompass regions that were previously occupied. However, ganglion cells in the degenerated retina have mainly shown a reduction in dendritic field size in this study and previous studies (Damiani et al., 2012). Additionally, ganglion cell loss, particularly in the central retina, is not significant at these ages (Damiani et al., 2012, Grafstei et al., 1972) and one study only reported a $20 \%$ reduction in the number of ganglion cells in the 3-6 month old $r d 1$ retina (Grafstei et al., 1972). Second, ganglion cells in the $r d 1$ retina may 
not develop normally as photoreceptor loss begins during retinal development which has been shown to have a detrimental effect on the synaptic connections between bipolar cells and photoreceptors (Blanks, et al., 1974, Strettoi and Pignatelli, 2000). This may potentially also affect other secondary neurons resulting in altered dendritic morphology as previously seen in some ganglion cells in the $r d l$ retina (Damiani et al., 2012). However, the results of another study show that the majority of ganglion cell types show normal morphology at 3 months of age (O'Brien et al., 2014).

A likely cause of the observed ganglion cell changes may result from remodelling events that occur in the later stages of degeneration (Jones et al., 2003, Marc and Jones, 2003). It is known that degeneration and remodelling of the inner retina occurs in patches across the retina (Marc and Jones, 2003) and is more heavily abundant in the central retina. Additionally, as retinal degeneration progresses these remodelling events become more extensive (Jones, et al., 2005). This is in agreement with the data presented here that indicates ganglion cell morphology changes at 11 months of age.

\section{Conclusions}

This study showed that several subclasses of ganglion cells were affected by retinal degeneration. Specifically, there was a decrease in size and complexity of A2, B1, C1 and D type ganglion cells in the central region of $r d l$-Thyl retina. It is thought that these ganglion cells in the central region of the retina were more susceptible to morphology changes than those in the peripheral region due to the remodelling events that also occur in this area. The changes in the dendritic composition of these ganglion 
cells will most likely impact the function of individual cells as well as the retinal circuitry in these areas in the degenerated retina.

\section{Acknowledgements:}

The authors are grateful to Cameron Nowell for assistance in using metamorph software and to A/Prof Tony Hannan for donating the Thy1-YFP mice. 


\section{References}

Blanks JC, Adinolfi AM, Lolley RN (1974) Photoreceptor degeneration and synaptogenesis in retinal-degenerative (rd) mice. Journal of Comparative Neurology 156:95-106

Dacey DM, Petersen MR (1992) Dendritic field size and morphology of midget and parasol ganglion cells of the human retina. Proceedings of the National Academy of Sciences of the United States of America 89:9666-9670

Damiani D, Novelli E, Mazzoni F, Strettoi E (2012) Undersized dendritic arborizations in retinal ganglion cells of the $\mathrm{rd} 1$ mutant mouse, a paradigm of early-onset photoreceptor degeneration. Journal of Comparative Neurology 520:1406-1423

Downie LE, Hatzopoulos KM, Pianta MJ, Vingrys AJ, Wilkinson-Berka JL, Kalloniatis M, Fletcher EL (2010) Angiotensin Type-1 Receptor Inhibition Is Neuroprotective to Amacrine Cells in a Rat Model of Retinopathy of Prematurity. J Comp Neurol 518:41-63

Downie LE, Pianta MJ, Vingrys AJ, Wilkinson-Berka JL, Fletcher EL (2007) Neuronal and glial cell changes are determined by retinal vascularization in retinopathy of prematurity. J Comp Neurol 504:404-417

Fletcher EL, Kalloniatis M (1996) Neurochemical architecture of the normal and degenerating rat retina. J Comp Neurol 376:343-360

Fletcher EL, Kalloniatis M (1997) Neurochemical development of the degenerating rat retina. J Comp Neurol 388:1-22

Grafstei B, Murray M, Ingoglia NA (1972) Protein-synthesis and axonal transport in retinal ganglion cells of mice lacking visual receptors. Brain Research 44:37-48

Hamel C (2006) Retinitis pigmentosa. Orphanet J Rare Dis 1:12

Greferath U, Anderson EE, Jobling AI, Vessey KA, Martinez G, de Iongh RU, Kalloniatis M, Fletcher EL (2015) Inner retinal change in a novel rd1-FT mouse model of retinal degeneration. Front Cell Neurosci 9:293

Jensen RJ, Rizzo JF (2007) Responses of ganglion cells to repetitive electrical stimulation of the retina. J Neural Eng 4:S1-S6

Jimenez AJ, GarciaFernandez JM, Gonzalez B, Foster RG (1996) The spatio-temporal pattern of photoreceptor degeneration in the aged $\mathrm{rd} / \mathrm{rd}$ mouse retina. Cell and Tissue Research 284:193-202

Jones BW, Watt CB, Frederick JM, Baehr W, Chen CK, Levine EM, Milam AH, Lavail MM, Marc RE (2003) Retinal remodeling triggered by photoreceptor degenerations. J Comp Neurol 464:1-16

Jones BW, Watt CB, Marc RE (2005) Retinal remodelling. Clin Exp Optom 88:282-291

Kalloniatis M, Fletcher EL (1993) Immunocytochemical localization of the amino-acid neurotransmitters in the chicken retina. J Comp Neurol 336:174-193

Lin B, Peng EB (2013) Retinal Ganglion Cells are Resistant to Photoreceptor Loss in Retinal Degeneration. PLoS One 8:

Marc RE, Jones BW (2003) Retinal remodeling in inherited photoreceptor degenerations. Mol Neurobiol 28:139-147

Marc RE, Jones BW, Watt CB, Strettoi E (2003) Neural remodeling in retinal degeneration. Prog Retin Eye Res 22:607-655

Marc RE, Jones BW, Watt CB, Vazquez-Chona F, Vaughan DK, Organisciak DT (2008) Extreme retinal remodeling triggered by light damage: implications for age related macular degeneration. Mol Vis 14:782-806 
Marc RE, Liu WLS, Kalloniatis M, Raiguel SF, Vanhaesendonck E (1990) Patterns of glutamate immunoreactivity in the goldfish retina. Journal of Neuroscience 10:4006-4034

Marc RE, Murry RF, Basinger SF (1995) Pattern-recognition of amino-acid signatures in retinal neurons. Journal of Neuroscience 15:5106-5129

Marc RE, Murry RF, Fisher SK, Linberg KA, Lewis GP, Kalloniatis M (1998) Amino acid signatures in the normal cat retina. Investigative Ophthalmology \& Visual Science 39:1685-1693

Margolis DJ, Newkirk G, Euler T, Detwiler PB (2008) Functional stability of retinal ganglion cells after degeneration-induced changes in synaptic input. J Neurosci 28:6526-6536

O'Brien EE, Greferath U, Fletcher E (2014) The effect of photoreceptor degeneration on ganglion cell morphology. J Comp Neurol 522:1155-1170

O'Hearn TM, Sadda SR, Weiland JD, Maia M, Margalit E, Humayun MS (2006) Electrical stimulation in normal and retinal degeneration (rd1) isolated mouse retina. Vision Research 46:3198-3204

Santos A, Humayun MS, de Juan E, Jr., Greenburg RJ, Marsh MJ, Klock IB, Milam AH (1997) Preservation of the inner retina in retinitis pigmentosa. A morphometric analysis. Arch Ophthalmol 115:511-515

Sekirnjak C, Jepson LH, Hottowy P, Sher A, Dabrowski W, Litke AM, Chichilnisky EJ (2011) Changes in physiological properties of rat ganglion cells during retinal degeneration. Journal of Neurophysiology 105:2560-2571

Strettoi E, Pignatelli V (2000) Modifications of retinal neurons in a mouse model of retinitis pigmentosa. Proceedings of the National Academy of Sciences of the United States of America 97:11020-11025

Strettoi E, Pignatelli V, Rossi C, Porciatti V, Falsini B (2003) Remodeling of secondorder neurons in the retina of $\mathrm{rd} / \mathrm{rd}$ mutant mice. Vision Res 43:867-877

Strettoi E, Porciatti V, Falsini B, Pignatelli V, Rossi C (2002) Morphological and functional abnormalities in the inner retina of the $\mathrm{rd} / \mathrm{rd}$ mouse. $\mathrm{J}$ Neurosci 22:5492-5504

Sun D, Vingrys AJ, Kalloniatis M (2007) Metabolic and functional profiling of the ischemic/reperfused rat retina. J Comp Neurol 505:114-130

Suzuki S, Humayun MS, Weiland JD, Chen SJ, Margalit E, Piyathaisere DV, de Juan E (2004) Comparison of electrical stimulation thresholds in normal and retinal degenerated mouse retina. Jpn J Ophthalmol 48:345-349

Wassle H, Boycott BB (1991) Functional architecture of the mammalian retina. Physiological Reviews 71:447-480 


\section{Tables}

Table 1: The number of retinal ganglion cells that were classified and analysed in control (Thy1) and $r d 1$-Thy1 mice

\begin{tabular}{|c|c|c|c|c|}
\hline \multirow{2}{*}{$\begin{array}{l}\text { Cell } \\
\text { Type }\end{array}$} & \multicolumn{2}{|c|}{ Thy1 $(n=4)$} & \multicolumn{2}{|c|}{ rd1-Thy1 (n=7) } \\
\hline & $\mathrm{C}^{*}$ & $\mathrm{P}^{\wedge}$ & $\mathrm{C}^{*}$ & $\mathrm{P}^{\wedge}$ \\
\hline A2 & 7 & 10 & 8 & 5 \\
\hline B1 & 3 & 10 & 8 & 6 \\
\hline C1 & 3 & 21 & 10 & 28 \\
\hline D & 6 & 20 & 3 & 7 \\
\hline
\end{tabular}

* $\mathrm{C}=$ central; ${ }^{\wedge} \mathrm{P}=$ peripheral

All cells were a re-analysis of those described in O'Brien et al 2014

Table 2: The number of retinal ganglion cells in control (Thy1) and $r d 1$-Thy1 mice.

Values are represented as mean \pm SEM.

\begin{tabular}{l|c|c|c|c}
\hline \multirow{2}{*}{$\begin{array}{l}\text { Age } \\
\text { (months) }\end{array}$} & \multicolumn{2}{|c|}{ Thy1 } & \multicolumn{2}{c}{ rd1-Thy1 } \\
\cline { 2 - 5 } & $\mathrm{C}^{*}$ & $\mathrm{P}^{\wedge}$ & $\mathrm{C}^{*}$ & $\mathrm{P}^{\wedge}$ \\
\hline $\mathbf{3}$ & $25 \pm 4.3$ & $58 \pm 2.1$ & $22 \pm 5.7$ & $30 \pm 6.8$ \\
$\mathbf{6}$ & $25 \pm 1.9$ & $53 \pm 3.8$ & $23 \pm 6.4$ & $40 \pm 4.6$ \\
$\mathbf{1 1}$ & $32 \pm 2.3$ & $81 \pm 5.7$ & $24 \pm 6.4$ & $49 \pm 12.1$ \\
\hline
\end{tabular}

$* \mathrm{C}=$ central; $\wedge$ $\mathrm{P}=$ peripheral 


\section{Figure legends}

Fig 1 Remodelling events in the $r d 1$ retina. Vertical sections of $r d 1$ retinae immunolabelled for glutamate, GABA, glycine and taurine. (a-c) A cell column (arrow) originates from the ganglion cell layer in the central retina of a 8 month $r d 1$ mouse. (df) Strictures (arrows) which are fragments of processes were seen in the inner nuclear layer of a 6 month $r d 1$ retina. (g,h) Glial hypertrophy (arrow) was evident from the subretinal position in the retina of a 8 month $r d 1$ mouse. (i) The total number of anatomical remodelling events in the central and peripheral regions of the retina at 3-5 months, 6-8 months and $>11$ months. There was a larger occurrence in the central retina at all ages and the total number of remodelling events increased with age.

Abbreviations: INL, inner nuclear layer; IPL, inner plexiform layer; GCL, ganglion cell layer. Scale bar seen in $(\mathrm{h})=20 \mu \mathrm{m}$

\section{Fig 2 Remodelling events in ganglion cell dendritic stratification the $r d 1$ retina.}

Retinal wholemounts were processed for fluorescence immunohistochemistry and 3D images of confocal z-stacks were tilted $90^{\circ}$ using Imaris software to visualise dendritic stratification. $(a, b)$ Representative ganglion cells in the Thy1 control retina stratifying in the middle (a) and ON sublayer (b) of the IPL. (c,d) Ganglion cells in the rd1-Thy1 retina stratifying into the $\mathrm{ON}$-sublayer of the IPL. Arrows indicate remodelled dendritic branches extending into the neighbouring layer. Scale bars $=20 \mu \mathrm{m}$.

\section{Fig 3 A2 type ganglion cells in the control and $r d 1$-Thy1 retina. Retinal}

wholemounts were processed for fluorescence immunohistochemistry and ganglion cells were analysed using metamorph software. $(a, b)$ Representative examples of A2 type ganglion cells in the Thy 1 and $r d l$-Thy1 retina in the central region. Scale bar $=$ 
$20 \mu \mathrm{m}$. (c-e) Analysis parameters of ganglion cells in central and peripheral regions.

Values are represented as mean \pm SEM. Differences between the mean responses were considered significant for $\mathrm{p}<0.05$ and are highlighted using bold font. When there was a significant interaction, the pairwise comparisons which were also significant are represented on the graphs using an asterisk. There was a significant decrease in the dendritic length of ganglion cells in the central retina. Additionally, there was a significant main effect of disease for all measured parameters

Fig 4 B1 type ganglion cells in the control and $r d 1$-Thy1 retina. Retinal wholemounts were processed for fluorescence immunohistochemistry and ganglion cells were analysed using metamorph software. $(\mathrm{a}, \mathrm{b})$ Representative examples of B1 type ganglion cells in the Thy 1 and $r d l$-Thy1 retina in the central region. Scale bar $=$ $20 \mu \mathrm{m}$. (c-e) Analysis parameters of ganglion cells in central and peripheral regions. Values are represented as mean \pm SEM. Differences between the mean responses were considered significant for $\mathrm{p}<0.05$ and are highlighted using bold font. When there was a significant interaction, the pairwise comparisons which were also significant are represented on the graphs using an asterisk. There was a significant decrease in the dendritic length and area in the central region of the $r d 1$-Thy1 retina

\section{Fig $5 \mathrm{C} 1$ type ganglion cells in the control and $r d 1$-Thy1 retina. Retinal}

wholemounts were processed for fluorescence immunohistochemistry and ganglion cells were analysed using metamorph software. $(\mathrm{a}, \mathrm{b})$ Representative examples of $\mathrm{C} 1$ type ganglion cells in the Thy 1 and $r d l$-Thy1 retina in the central region. Scale bar $=$ $20 \mu \mathrm{m}$. (c-e) Analysis parameters of ganglion cells in central and peripheral regions. Values are represented as mean \pm SEM. Differences between the mean responses were 
considered significant for $\mathrm{p}<0.05$ and are highlighted using bold font. When there was a significant interaction, the pairwise comparisons which were also significant are represented on the graphs using an asterisk. There was a significant decrease in all measured parameters in the central region of the $r d l$-Thy1 retina

Fig $6 \mathrm{D}$ type ganglion cells in the control and $r d 1$-Thy1 retina. Retinal wholemounts were processed for fluorescence immunohistochemistry and ganglion cells were analysed using metamorph software. $(a, b)$ Representative examples of D type ganglion cells in the Thy1 and $r d 1$-Thy1 retina in the central region. Scale bar $=20 \mu \mathrm{m}$. (c-e) Analysis parameters of ganglion cells in central and peripheral regions. Values are represented as mean \pm SEM. Differences between the mean responses were considered significant for $\mathrm{p}<0.05$ and are highlighted using bold font. When there was a significant interaction, the pairwise comparisons which were also significant are represented on the graphs using an asterisk. There was a significant decrease in all measured parameters in the central region of the $r d l$-Thyl retina 


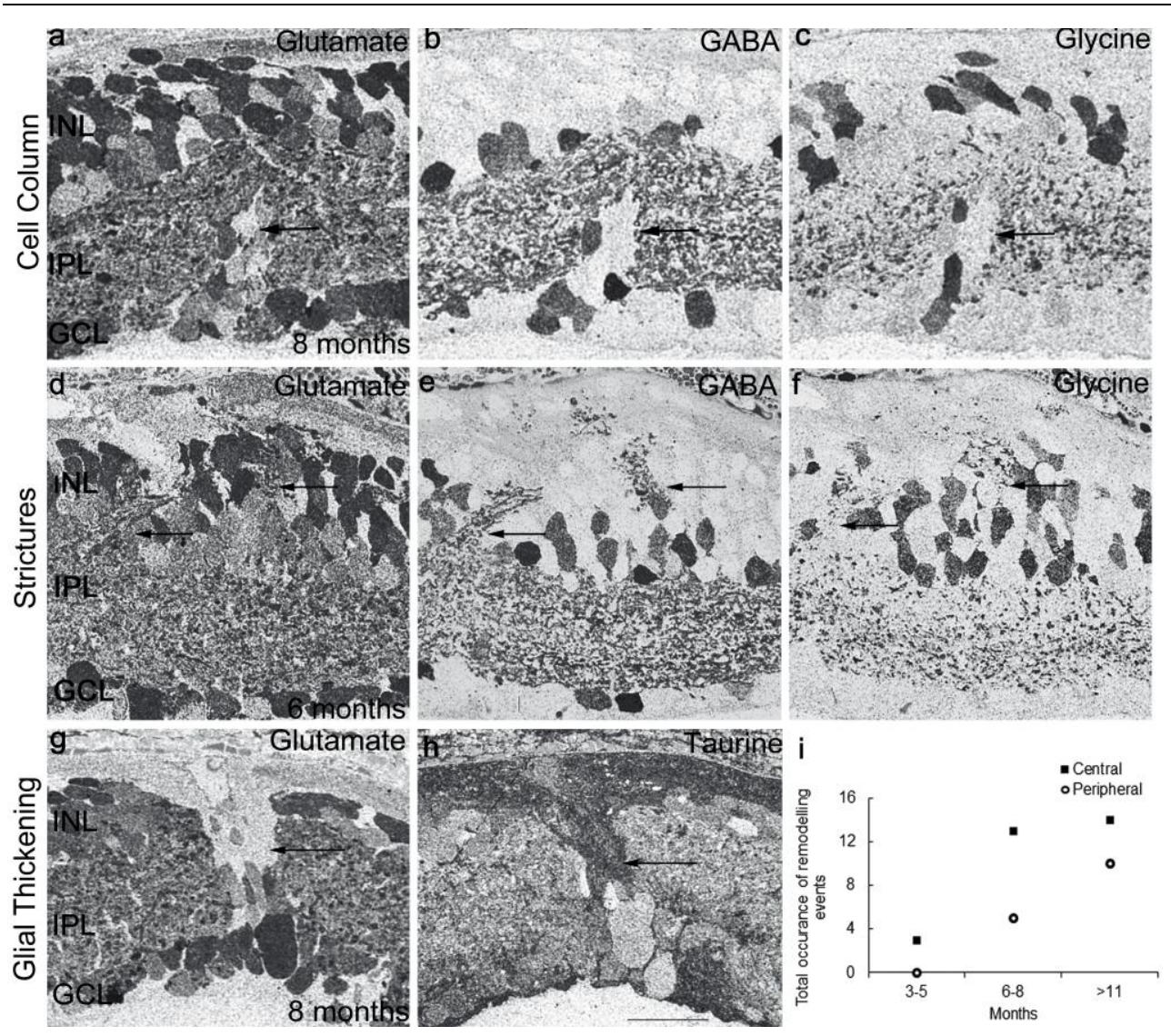



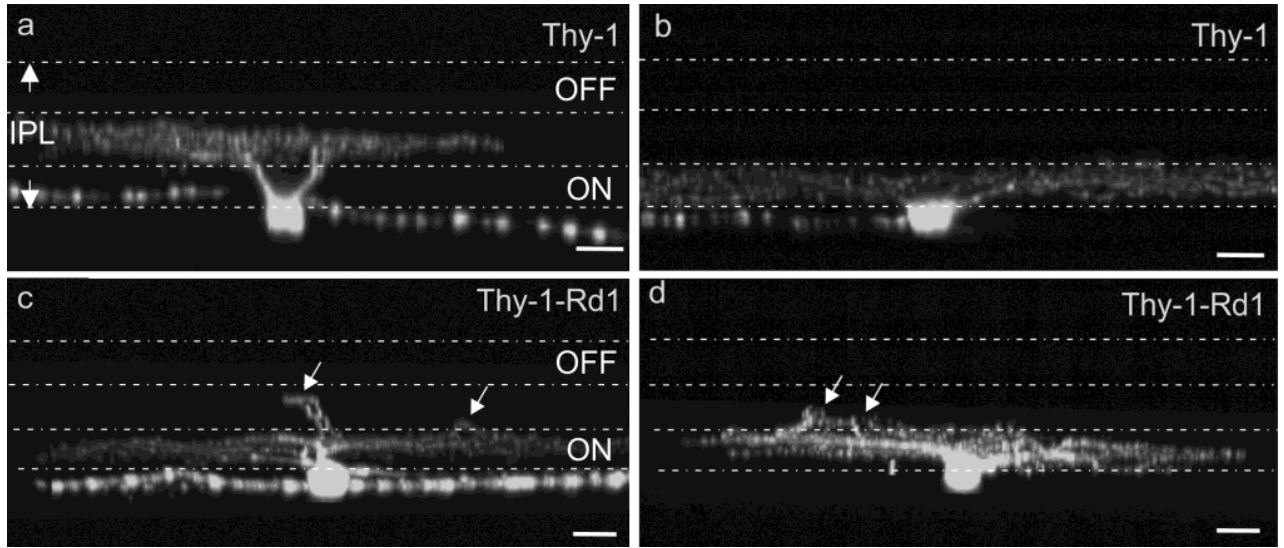

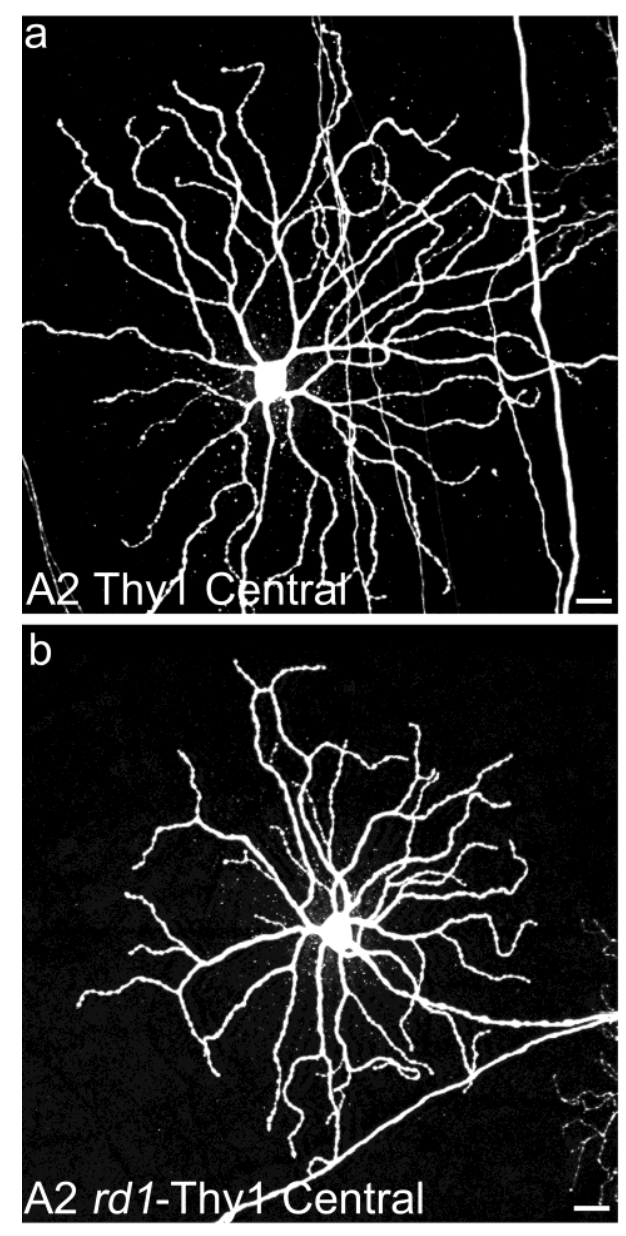

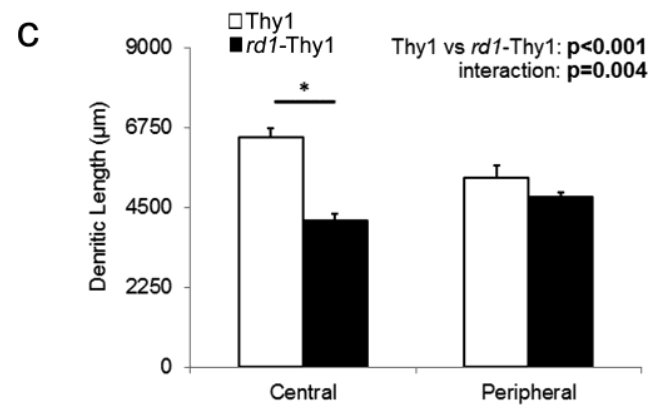

d

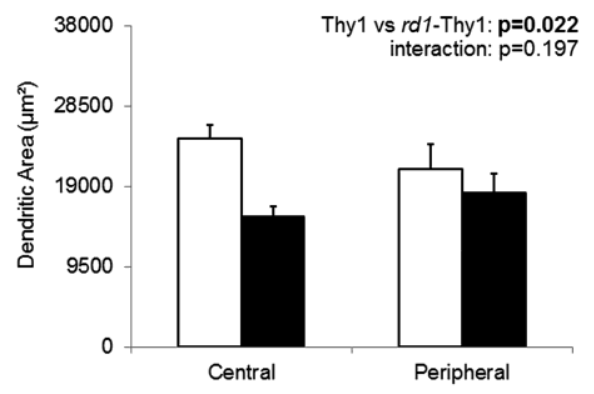

e

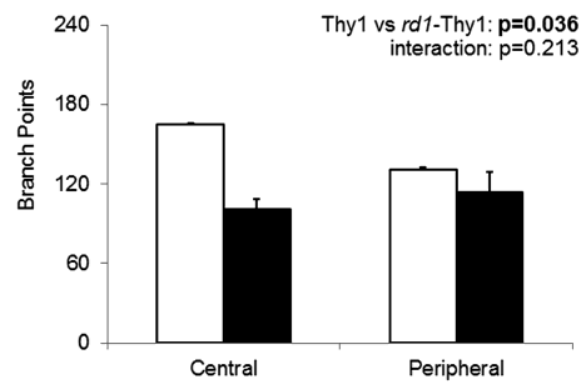



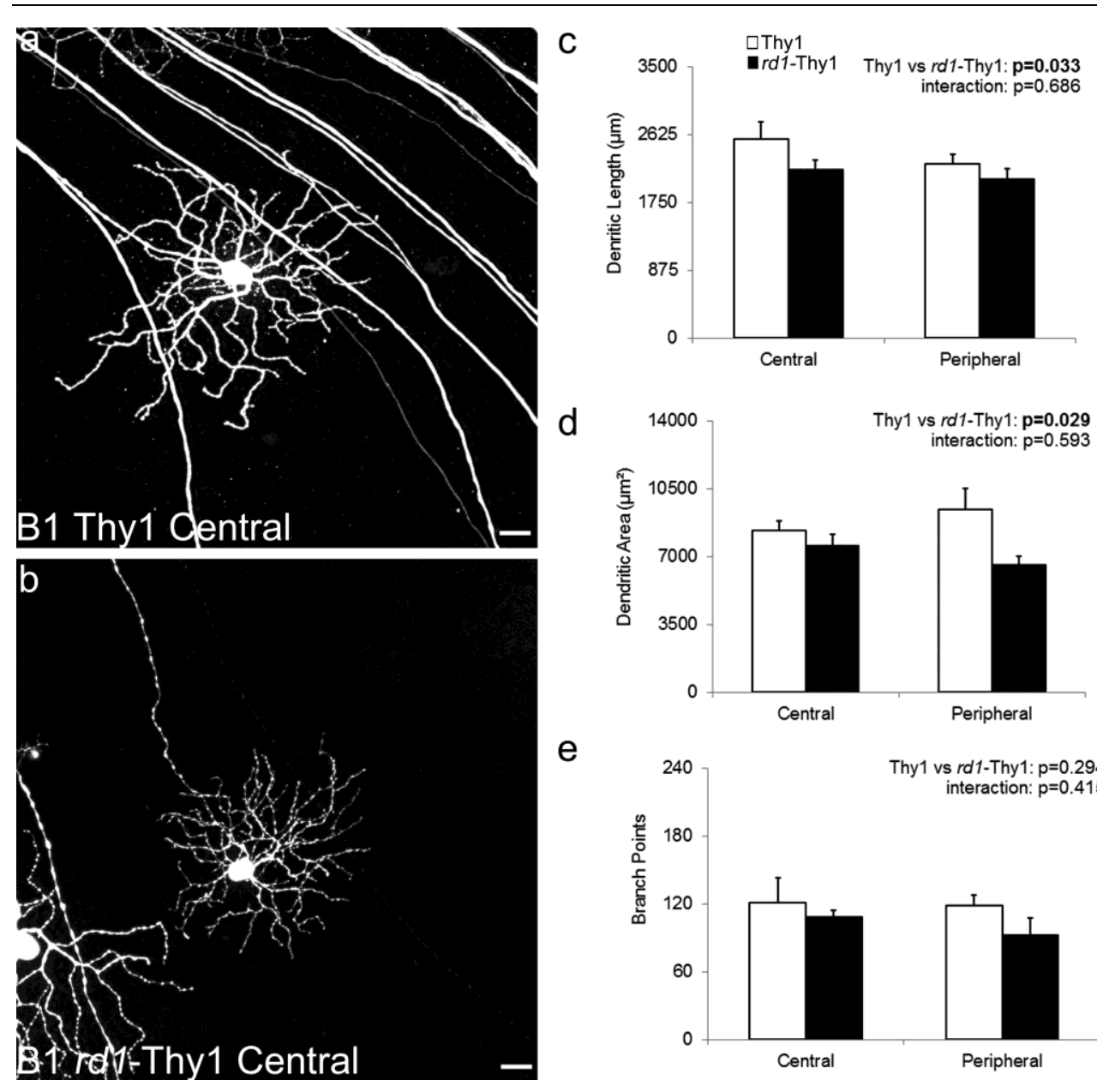

e

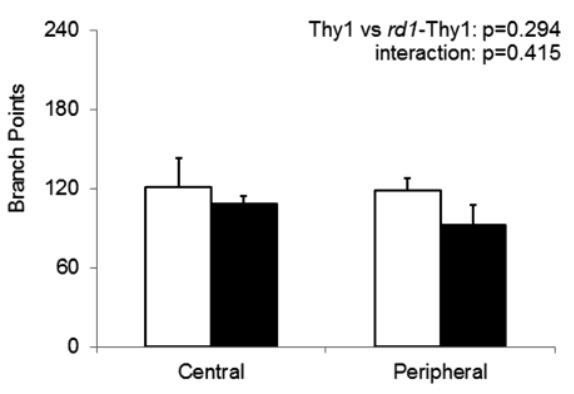




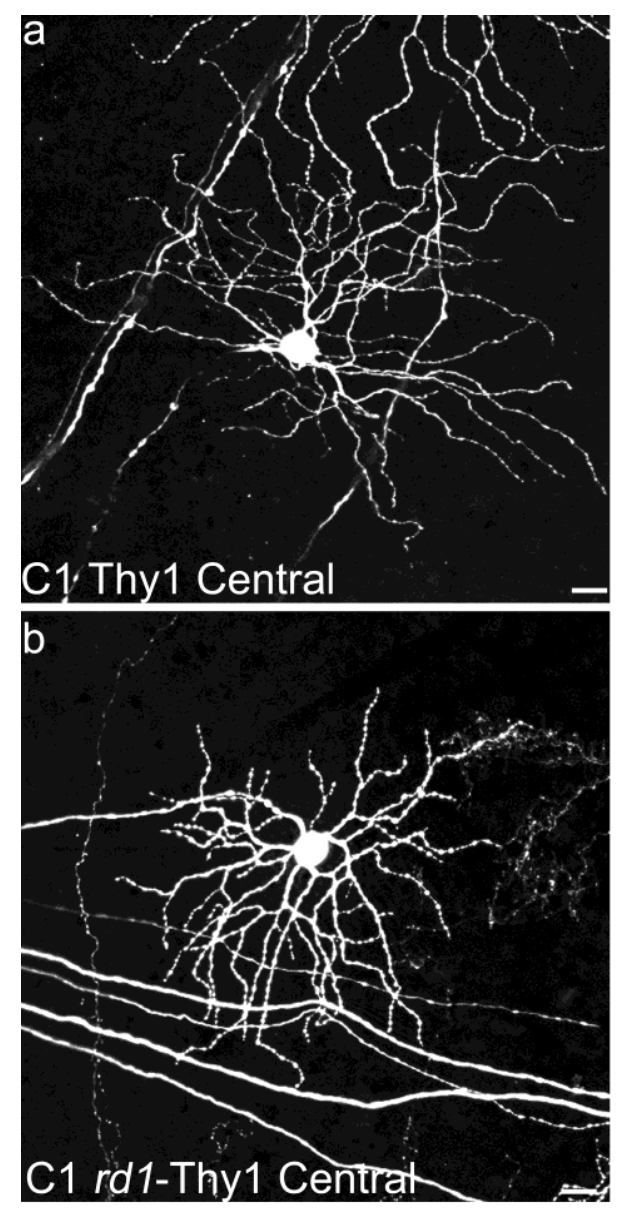

C

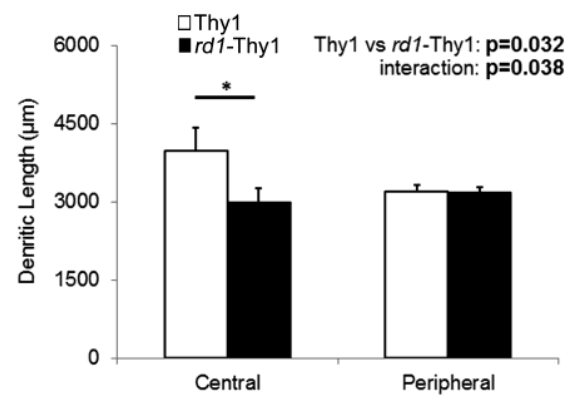

d
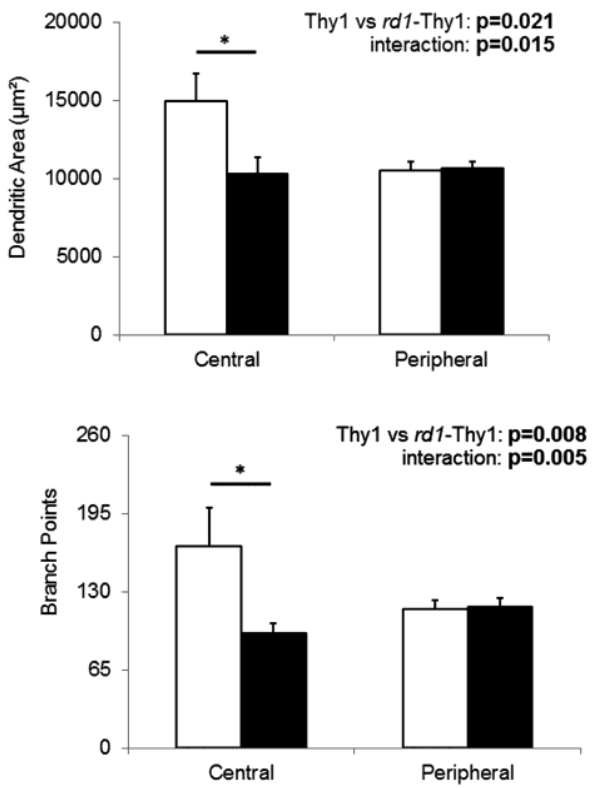

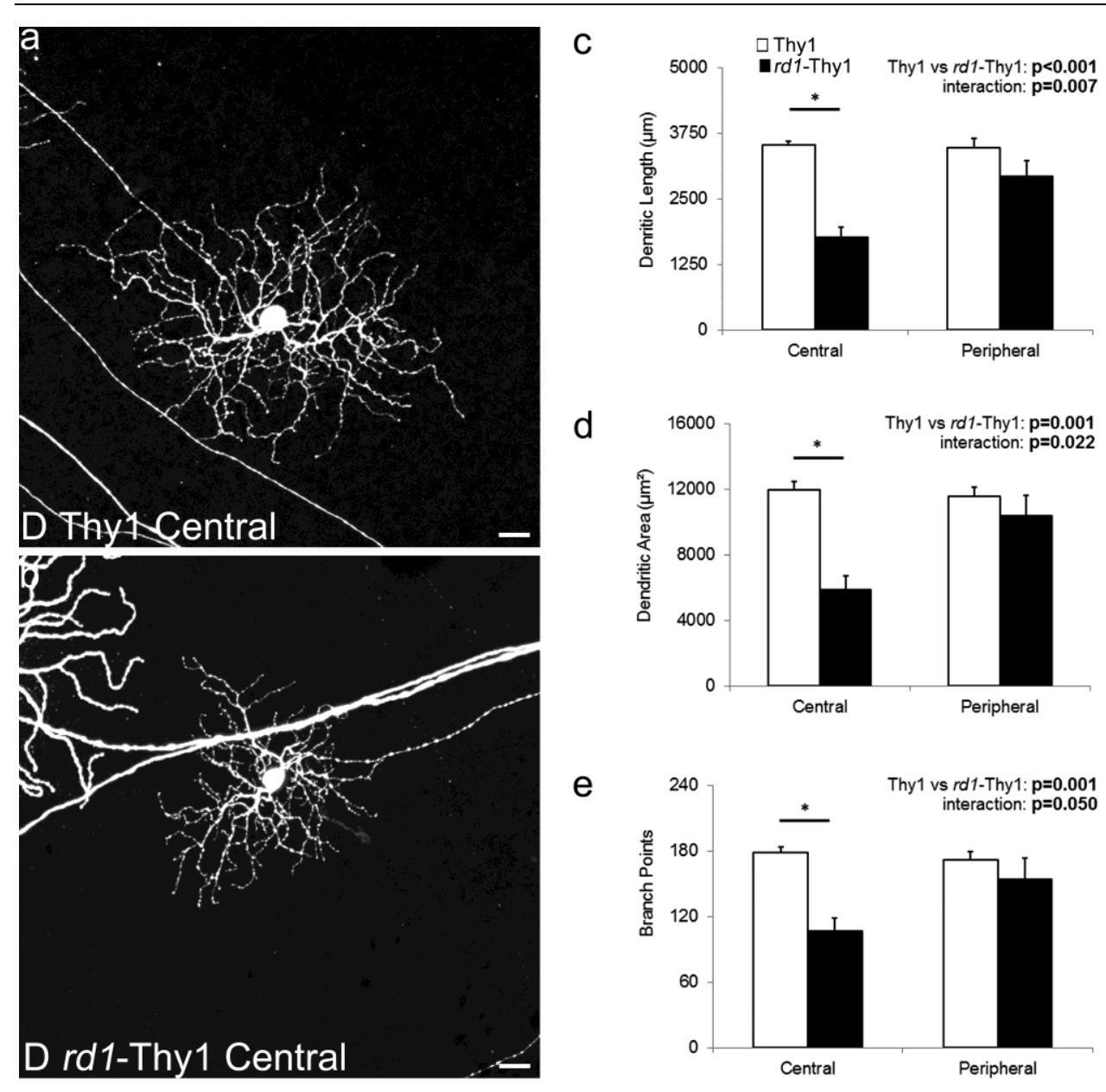